Article

\title{
Nordic Security and Defence Cooperation: Differentiated Integration in Uncertain Times
}

\author{
Rikard Bengtsson \\ Department of Political Science, Lund University, 22100 Lund, Sweden; E-Mail: rikard.bengtsson@svet.lu.se
}

Submitted: 12 June 2020 | Accepted: 28 August 2020 | Published: 3 November 2020

\begin{abstract}
A decade ago, Nordic cooperation on security and defence matters gained momentum, having been largely absent from the map of Nordic cooperation during the Cold War and its aftermath. This article analyses developments along three dimensions of Nordic cooperation: military defence (focusing on the Nordic Defence Cooperation), civil security (in the form of the 'Haga' process), and political cooperation (through the implementation of the Stoltenberg report). Three observations stand out as a result: First, that the three dimensions are intimately related against the background of a common Nordic conceptualization of security; second, that there is simultaneously variation in significant respects (such as driving forces, scope, and degree of institutionalization); and third, that Nordic security and defence cooperation has developed in the context of European and transatlantic security dynamics and cooperation. The second part of the analysis seeks to interpret this picture from the analytical perspective of differentiated integration. The article ends with a set of reflections on the future of Nordic security and defence cooperation in light of the Coronavirus pandemic.
\end{abstract}

\section{Keywords}

civil security; cooperation; defence; differentiated integration; Haga process; NORDEFCO; Nordic; security; Stoltenberg

\section{Issue}

This article is part of the issue "Rediscovering Nordic Cooperation" edited by Anne Elizabeth Stie (University of Agder, Norway) and Jarle Trondal (University of Agder, Norway/ARENA University of Oslo, Norway).

(C) 2020 by the author; licensee Cogitatio (Lisbon, Portugal). This article is licensed under a Creative Commons Attribution 4.0 International License (CC BY).

\section{Introduction}

The last decade has seen a surge in Nordic cooperation in the area of security and defence. This is all the more surprising given the absence of such cooperation during the Cold War and the different securitypolitical orientations and institutional linkages of the Nordic countries: with Norway, Denmark, and Iceland being North Atlantic Treaty Organization (NATO) members whereas Sweden and Finland remained non-aligned, and with Denmark, Finland, and Sweden being European Union (EU) members while Norway and Iceland opted for non-membership cooperation. Indeed, Nordic cooperation and integration was in many ways a success story during the Cold War, with intensifying cooperation and even integration in a number of societal fields. As explored further below, security and defence was however not part of this process. Described by Forsberg as the "golden era of Nordic cooperation" (2013, p. 1163), the
Cold War saw the formation of the Nordic Council in 1952 , a permanent treaty on Nordic cooperation in 1962, and the Nordic Council of Ministers, established in 1971. Sometimes overlooked due to its relatively weak institutional foundations, Nordic cooperation advanced during the first decade of the Cold War to include things such as a passport union (1952), a common labour market (1954), and a reciprocal social security arrangement (1955). Later advances included a language convention and the Nordic Investment Bank.

Having said that, the Cold War period also contained major failures of cooperation, most notably the idea of a Nordic single market and the Nordic Economic Community (NORDEK); in the latter case a reflection of Denmark's and Norway's decision to opt for the European Economic Community instead (although in Norway's case, the government's proposal to join was defeated in a referendum).

Deliberately, foreign, security and defence policy cooperation was not made part of the mandate for the 
Nordic Council as it would have made Finnish membership in the Council impossible given Finland's special relationship to the Soviet Union. Moreover, following the failed negotiations for a Nordic defence alliance in 1949 and Denmark's, Norway's, and Iceland's decision to join NATO, regional security and defence cooperation was not really deemed politically feasible or of great valueadded by anyone in the region.

During the Cold War, then, Nordic defence cooperation was essentially limited to cooperation in the context of United Nations (UN) peacekeeping. The Nordic states, apart from Iceland, established the NORDSAMFN forum in 1963 as a group for Nordic cooperation on military UN matters. This was supplemented the following year by a joint Nordic stand-by force at the UN's disposal (NORDBERFN). In 1997, these arrangements were replaced by NORDCAPS (Nordic Coordinated Arrangement for Military Peace Support, later to become an integral part of today's cooperation scheme-see further Forsberg, 2013, p. 1167). Nordic cooperation in the context of UN peacekeeping can be understood as a way of balancing different security-political orientations (NATO membership and non-alignment, often referred to as 'the Nordic balance') and a common small state security identity (reflected in UN-mandated international activism).

Today, the situation is fundamentally different in important respects, as cooperation in security and defence has not only been introduced but has arguably risen to the top of the agenda of Nordic cooperation. Still, certain structural preconditions remain, notably the different institutional linkages. Three inter-related dimensions make up security and defence cooperation among the Nordic countries today: military defence cooperation, civil security cooperation, and a political process for advancing cooperation on foreign policy, security, and defence. This article aims to map this evolving landscape of Nordic security and defence cooperation and critically examine the nature and dynamics of cooperation in this sphere utilizing scholarship on differentiated integration, complemented by the concepts of security community and stable peace.

Before exploring the different dimensions of cooperation, a note on terminology is necessary: Non-military security and defence cooperation features under an array of labels in academic scholarship as well as in Nordic and European politics - civil defence, civil security, emergency preparedness/management, crisis readiness, civil protection etc. For reasons of conceptual clarity, this article will reserve the term defence for military defence and primarily use the label civil security when discussing nonmilitary aspects of security and defence. Civil defence may still feature in the text in the context of official documents and statements.

\section{Military Defence Cooperation}

Nordic cooperation in military defence takes place within the framework of the Nordic Defence Cooperation
(NORDEFCO). Founded in 2009, NORDEFCO's aim is to "strengthen the participating nations' national defence, explore common synergies and facilitate efficient common solutions" (NORDEFCO, 2020). While the aim remains the same, the motivation for Nordic defence cooperation has changed fundamentally, from economic reasons (cost-effectiveness) to managing the Russian challenge, to security in the Baltic Sea region. How did we end up here?

The end of the Cold War implied substantial changes to the Nordic security situation, as Sweden and Finland joined the EU and engaged in close collaboration with NATO. This is reflected in examples of closer cooperation among the Nordic countries in military affairs, such as joint armaments projects, cooperation in NATO-led operations in Afghanistan and the Balkans, and the establishment of the Nordic Battle Group in the EU context.

The process of closer collaboration can be traced back to 2006-07 and a Swedish-Norwegian bilateral initiative for cooperation (on exercises and education as well as on maintenance and upgrading of equipment) as a way to cope with the increasingly challenging economic situation (rapid cost development of equipment in parallel to sliced defence budgets as a result of a conducive security environment). In 2008, a trilateral working group (Sweden-Finland-Norway) identified as many as 140 areas of potential bilateral and trilateral cooperation -40 of which could have been initiated more or less immediately (Bailes \& Sandö, 2014, pp. 12-13; Forsberg, 2013, pp. 1167-69; Saxi, 2019, p. 663). Finland's reason for joining Norway and Sweden was "the very great challenges facing the country's defence economy" (Saxi, 2019, p. 664).

In November 2008, then, the five Nordic states signed a memorandum of understanding establishing NORDSUP (Nordic Supportive Defence Structures) as a new scheme for cooperation. A year later NORDSUP was combined with two other existing formats for cooperation (NORDAC-Nordic Armaments Cooperation and NORDCAPS-Nordic Coordinated Arrangement for Military Peace Support) to become NORDEFCO. The idea was to "produce national military capabilities in a more cost-efficient way by means of multinational cooperation" (Röksund as cited in Saxi, 2019, p. 665).

Hence by 2009, a pan-Nordic framework for military cooperation was in place, driven by an economic rationale and initiated from within the defence forces, but widely supported by Nordic politicians and the Nordic public (according to a study by Oxford Research, referred in Saxi, 2019, p. 665). It is to be noted, however, that for a number of years it remained primarily a Norwegian-Finnish-Swedish project, with limited engagement from Denmark and Iceland. Iceland's special precondition-lacking military forces of its ownexplains its purely political orientation. In Denmark's case, the situation was different: Its security policy approach had an explicit Atlanticist orientation and was directed at the United Kingdom and especially the United 
States. It also maintained a different profile of its defence forces, applying a clear alliance logic and focusing on selected aspects-niche capabilities-for participation in expeditionary coalition operations. This was in sharp contrast to Finland's, Norway's, and to a degree also Sweden's ambition to maintain conventional defence forces (see Forsberg, 2013, p. 1173).

Early examples of NORDEFCO cooperative activities include training and exercises, for instance among the Finnish, Swedish and Norwegian air forces on a weekly basis, participation in each other's exercises, and regarding international operations (such as joint weekly transport flights to Afghanistan). While these efforts were realized quite swiftly and with notable benefits, cooperation that required a more fundamental restructuring of the armed forces in order to achieve what is sometimes referred to as "system similarity" (Saxi, 2019, p. 668) was much more difficult and less successful. A case in point is materiel acquisition, which proved difficult to achieve, both because of incompatible preferences (such as Denmark and also Norway opting for American aircraft instead of the Swedish Gripen) and different demands, evident not least on the maritime side with there being quite different geographical situations.

In the early 2010s, the enthusiasm for Nordic military defence cooperation had clearly weakened; there was no longer the political will to make the effort (Saxi, 2019 , p. 670). Russia's annexation of Crimea and military interference in Ukraine fundamentally changed the situation. The events of spring 2014 contained two interrelated elements of relevance for the future of Nordic military defence cooperation. One was the political will to spend considerably more on national defence (which in effect reduced the relevance of the earlier economic argument for defence cooperation), the other the realization that the Nordic (and Baltic) states were all part of an interdependent security region defined by the major fault line between Russia and NATO (see for instance NORDEFCO, 2014).

Nordic cooperation thus reappeared on the political scene, but as a solution to a different problem than before-not economic difficulties but the Russian threat. Saxi argues that economic logic, as well as the hitherto conducive security situation, proved not to be enough for deeper cooperation: "These internal drivers were insufficiently powerful to lead the Nordic countries down the path of integrating their armed forces" (Saxi, 2019, p. 662). With the Russian annexation of Crimea and the Ukraine crisis, the security situation in Northern Europe took on a different dynamic-and Nordic defence cooperation from 2014 onwards became threat-driven.

In consequence, the Nordic governments expressed their common stance that Russia's activities in 2014 were responsible for the deteriorating security situation in Europe and that enhanced Nordic military cooperation (bilaterally and multilaterally) would be a key part of managing the situation (Regeringen, 2015). Sweden and Finland were in a special situation given that they were/are not part of NATO. A key development since 2014 has been both of them drawing closer to NATO (based on already close partnerships), a reflection of the perceived importance of NATO as the primary institution for managing the Russian military threat. In consequence, both countries have, for instance, ratified host nation support agreements. Their bilateral relationship has subsequently developed through discussions on how to cooperate during times of crisis and even war, including establishing a memorandum of understanding to cover "operational planning in all contingencies," as stated in 2018 by the Finnish Commander of the Defence Forces Jarmo Lindberg (Lindberg, 2018, p. 18; see also Hultqvist, 2020). Also, legal preparations to receive and give military support (see further Saxi, 2019, p. 673) are now materializing in the form of a bilateral host nation support agreement being set up (Hultqvist, 2020). Both have also sought closer contact with key Western states - with the United Kingdom regarding joining the Joint Expeditionary Force, with Germany regarding the Framework Nations concept, and with the United States, with which a trilateral defence relationship was formalized through the signing of a letter of intent in May 2018 (Regeringen, 2018).

NORDEFCO has seen renewed enthusiasm and importance as a multilateral platform for security and defence discussions and dialogue and for secure communication channels between the Nordic capitals on both the political and military levels. Headed by the ministers of defence (in Iceland's case the foreign minister), cooperation is conducted by the Policy Steering Committee of senior civil servants and assisted by the Military Coordination Committee (see further NORDEFCO, 2020). Today, practical cooperation covers a wide range of activities, organized into five cooperation areas: capabilities, armaments, human resources and education, training and exercises, and operations. Prominent examples of concrete cooperation include air surveillance, enhanced cross-border mobility (with less bureaucracy) for the Nordic defence forces (for instance opening up airbases as alternate landing sites), and large-scale training and exercises as practical means for increasing interoperability (examples include the Aurora 17 and Trident Juncture exercises in 2017 and 2018 with large numbers of troops from Nordic as well as NATO countries).

In contrast to the early NORDEFCO years, the new security situation has made Denmark engage in Nordic cooperation more intensely, both as a part of NATO's management of the Baltic Sea region and directly in relation to the Nordic countries, notably Sweden, with which it signed an agreement in 2016 for better access to each other's air and sea territory and for the exchange of air surveillance data (Regeringen, 2016; on Denmark's reorientation, see also Herolf \& Håkansson, 2020, p. 10).

Looking to the future, the NORDEFCO Vision 2025 (agreed by the Defence Ministers in November 2018) is founded on the conviction that "security challenges in our region are becoming more complex and demanding" 
and is centred on the idea of transferring the current peace-time framework into something that would apply also during crisis and conflict (operationalized into 16 different target points; NORDEFCO, 2018).

Implementation continues in key areas of the 2025 vision, notably the NORDEFCO Crisis Consultation Mechanism for enhanced information sharing and consultations during crisis and conflict. The Alternate Landing Bases arrangement has been extended to also include armed aircraft. The Arctic Challenge Exercise, conducted in 2019, was the largest air exercise in Europe during the year, involving some 10,000 personnel from Finland, Norway, Sweden, the UK, and the US (NORDEFCO, 2019).

\section{Cooperation on Civil Security}

2009 proved to be an important year in Nordic security and defence cooperation. Not only was the military side formalized through the birth of NORDEFCO, but cooperation on civil security also deepened substantially, as the Nordic ministers responsible for civil security and emergency management agreed to the so-called 'Haga' declaration on Nordic cooperation in areas of civil security and crisis preparedness (named after the venue for the meeting, a royal estate in Stockholm; MSB, 2009).

The background to this development is to be found in a number of areas. There had been elements of Nordic civil security cooperation also before the Haga process; for instance, the NORDRED system for cooperation among national rescue services, and police cooperation on cross-border crime and terrorism. Moreover, there were institutional foundations for deepening cooperation, not least through the actions of the Nordic Council of Ministers. The environment was, in other words, conducive to advancing cooperation. But, importantly, the development is also a reflection of both tragic events in real life (notably the 2004 tsunami in the Indian Ocean), and a reorientation and convergence of conceptualizations of security among the Nordics towards a comprehensive rather than primarily military notion. Moreover, different forms of political entrepreneurship by the Nordic Council (aimed at a border-free Nordic zone) and by Sweden (reflecting its own security reorientation) played a role, as did the realization that outside help for dealing with non-military security threats was in limited supply (see further Bailes \& Sandö, 2014, pp. 13-17, 23-25).

The content of the Haga declaration and subsequent concrete measures reflect a very broad palette of topics, ranging from search and rescue and preparedness against CBRN accidents to crisis communication and strategic air transport to emergency areas. Bailes and Sandö argue that it is hard to see any overarching logic of the evolving cooperation apart from "a combination of national 'favourites' and avenues of least resistance" (Bailes \& Sandö, 2014, p. 27). Importantly though, as of 2012, a working group was set up to work on a more ambitious Haga declaration, which materialized in 2013.

This 'Haga II' declaration and process thus rest on the development of deeper cooperation and a clear political interest in the field of civil security and emergency management issues, but lacking explicit priorities and strategic direction. The new process was different in this regard as it was set on a common formulation of societal security and encompassed the 2011 solidarity declaration among the Nordic countries (see further next section). The new vision can be described as a robust and resilient Nordic region without internal borders (MSB, 2013,2018 , p. 11). A central idea was to advance a strategic development plan during the first year of Haga II, rather than adding isolated projects without a comprehensive idea of direction. More specifically, two studies were made the centre of the work process: an audit of relevant cooperation and a study of the preconditions for intra-Nordic host nation support (see further Bailes \& Sandö, 2014, p. 33).

Tracing the development further, the ministerial meeting in 2015 decided on a set of twelve points for deeper cooperation, including enhanced sharing of experiences in crisis preparedness and management, assessment of cross-border risks and ability to deal with these, and practical preconditions to receive and provide support among the Nordic countries on the basis of the declaration of solidarity (MSB, 2018, p. 11).

The organization of the Haga process consists of annual ministerial meetings (though often attended by State Secretaries or other senior officials), a working group of officials from relevant ministries, and meetings of the Directors-General of the implementing agencies of each country (MSB, 2018, pp. 12-13). Reflecting the complex nature of the field as well as different organizing principles in different countries, the relevant ministries have been those of Justice, Defence, and Interior (different in different countries and also shifting over time in the same country).

Beyond cooperation at the Nordic level, there are in some areas bilateral and trilateral cooperation, particularly among Sweden, Norway, and Finland. Further deepening of cooperation in the area of civil security has been called for, not least by the Swedish parliamentary defence commission, focusing on issues such as supply security, transport and logistics, critical infrastructure, and health issues. The agreement between Sweden and Finland on economic cooperation in times of international crisis (from 1992) has been suggested as a basis for such bilateral and trilateral cooperation (MSB, 2018, p. 15).

A key element in the Haga process has been the centrality of the EU, both for political input and context and, perhaps more importantly, for money (many activities of the Haga process have involved seeking, and being granted, co-funding from the EU; Bailes \& Sandö, 2014, p. 34). Furthermore, all Nordic countries are part of the EU's Civil Protection Mechanism and all countries except 
Iceland provide input into the Civil Protection Pool of resources for joint use in the EU.

Here NATO cooperation on civil security matters should also be noted: All Nordic countries are part of NATO's civil emergency cooperation, which is focused around three functions (continuity of government, continuity of essential services to the population, and civil support to military operations; NATO, 2020). Nordic ambitions to deepen cooperation on civil security and defence, therefore, involves not only the EU but also NATO.

\section{Nordic Political Cooperation on Security and Defence}

The third aspect of Nordic security and defence cooperation can be conceptualized as providing political direction. Again, 2009 is in focus. Thorvald Stoltenberg (former Foreign Minister of Norway) presented his Nordic Cooperation in Foreign and Security Policy report to the Nordic foreign ministers in Oslo in February of that year (Stoltenberg, 2009). The ministers had commissioned the report the summer before as a forward-looking analysis of a deepening of practical cooperation in the areas of foreign policy, security, and defence. The Stoltenberg report contained 13 proposals of a rather different character, varying substantially in scale and political feasibility. Reactions to the report were primarily positive, although certain criticisms were levelled from various corners (Forsberg, 2013, p. 1170). Given the forward-looking and in some respects quite drastic nature of the report, the initial implementation of the proposals was slow.

Two proposals stand out as particularly important, one concerning the already mentioned air surveillance of Icelandic airspace. The key question revolved around compatibility with Swedish and Finnish non-alignment. In 2012 both countries agreed to be part of the arrangements from spring 2014 onward, under the condition that the operation was categorized as surveillance and not policing, which would require legal changes (and may be difficult to get public acceptance for). Simultaneously, NATO announced that it would take care of possible interception flights (Forsberg, 2013, p. 1170). A second particularly important proposal, indeed the most far-reaching of them all, was the idea of a Nordic solidarity declaration. Stoltenberg envisioned a Nordic security guarantee that in binding terms would declare how the Nordics would respond "if a Nordic country were subject to external attack or undue pressure" (Stoltenberg, 2009), arguing that this would be natural given that the Nordic states have a lot in common and share a common history and identity, and that the Nordic countries in other ways (through EU and NATO) have commitments in relation to countries with which they have far less in common. A case in point concerns Sweden, which as part of its reformulation and reinterpretation of its non-alignment policy has a unilateral solidarity clause vis-à-vis the other Nordic countries and fellow EU member states, as decided by the Swedish Parliament in 2009.
After a period of political preparation, a Nordic solidarity declaration was agreed in Helsinki in 2011. Adjustments had been made in relation to Stoltenberg's original idea to the effect that it was no longer a formal defence obligation but rather an arrangement that resembles the EU's solidarity clause (article 222 in the Treaty on the Functioning of the European Union), focusing on natural and man-made disasters, terrorism and cyber-attacks (i.e., not military threats, thereby avoiding sensitive issues about compatibility with NATO obligations; see further Saxi, 2019, p. 665). Notably, the solidarity declaration explicitly situates Nordic commitments so as to "complement existing European and Euro-Atlantic cooperation" (Regjeringen, 2011). It should be emphasized, moreover, that in contrast to the solidarity clause in the EU, which is written into the EU treaty and legally binding, the Nordic solidarity declaration is a ministeriallevel expression of solidarity, and not a formalized agreement. The wording and reach of the two are substantially similar, however.

Analysing the implementation of the 13 proposals, the picture is quite varied. In a report from a set of Nordic think tanks, it is concluded that implementation of the Stoltenberg proposals has varied quite fundamentally. Few of the proposals have been implemented in full and others have been partially implemented but as part of other frameworks (primarily EU and NATO). Still, it is reasonable to conclude, along the lines of the implementation assessment, that "the (Stoltenberg) report has been important in changing the overall approach and perspective of Nordic cooperation" (Haugevik \& Sverdrup, 2019, p. 4). Notably, however, the assessment report finds no case of significant progress based solely on intra-Nordic cooperation. There are areas of significant progresscooperation on surveillance of Icelandic airspace and a Nordic rescue network to protect against cyber-attacksbut these are supplemented by either NATO as in the first example, or the EU and NATO in the second.

Partial progress can be detected regarding three of the proposals based on intra-Nordic cooperationestablishing a disaster response unit, on military cooperation (about transport, medical services, education, material and exercise ranges), and on the Nordic declaration of solidarity discussed above. Some other areas of partial progress (understood as the existence of planning and containing small steps of implementation) may be found-a maritime response force, cooperation on Arctic issues, a Nordic maritime monitoring system, and establishing an amphibious unit-but, again, with the involvement of external parties (the Arctic Council and the Arctic Coast Guard forum regarding the first two, the EU regarding the latter two). Three of 13 proposals have seen no progress at all (establishing a Nordic stabilization force, a satellite system for surveillance and communications, and a war crimes investigation unit; Haugevik \& Sverdrup, 2019). Regarding Stoltenberg's proposal for cooperation among Nordic diplomatic services, finally, significant developments can be found. The assessment 
report classifies these as supplemented by an external body, which could be debated-rather it is to say that what is now in place (instances of co-location and shared representation regarding immigration) was already significantly in place before Stoltenberg, and despite positive rhetoric, little progress has been made since.

A decade after Stoltenberg's report, the debate about taking political cooperation on security and defence matters one step further is increasingly vocalagainst the background of a dramatically different security context compared to ten years ago. The Nordic foreign ministers decided at a meeting in conjunction with the Nordic Council session in October 2019 to initiate a new analysis of preconditions for deepening Nordic cooperation on foreign and security policy-popularly referred to as Stoltenberg $\mathrm{II}$-to be conducted by the Icelandic politician and former minister Björn Bjarnason and to be completed by mid-2020 (Nordic Council, 2019). Bjarnason delivered his report on 6 July 2020 and a first implementation discussion is to be held by the Nordic Foreign Ministers in September 2020 (Regeringen, 2020). While it is, of course, impossible to know the faith of the different proposals at the time of writing, it is principally interesting for our purposes to note that the three main themes which organize the 14 proposals-global climate change, hybrid threats and cyber issues, and multilateralism and a rules-based world order-clearly problematize the civilian/military distinction and are based on a broad conceptualization of security (Bjarnason, 2020).

\section{Nordic Cooperation on Security and Defence: Key Observations}

Three key observations result from this assessment of security and defence cooperation over the last decade, First, the three dimensions of Nordic security and defence cooperation are deeply interrelated, reflecting shared conceptualizations of security by the Nordic states. While employing different terminology, all the Nordic states embrace a perspective on security much broader than merely upholding the territorial integrity of the state; rather it is societal security (the functionality of society and the safety and well-being of its citizens) that is the overarching security doctrine (see further Bailes \& Sandö, 2014, pp. 8, 21, 48). In that vein, it can be noted that civil security aspects have also needed development in light of the deterioration of the regional security environment in recent years (MSB, 2018, pp. 5, 12); Bjarnason's report on future cooperation is the latest expression thereof (Bjarnason, 2020).

A second key observation concerns variation. As shown above, the three sectors of cooperation vary along a number of dimensions, including intensity, scope, degree of institutionalization, and driving forces. Interestingly, variation can be found also within each sector of cooperation. Moreover, variation also concerns format: While many things are done 'at Five' there is also a host of bilateral and trilateral processes of coopera- tion. These patterns of variation are simultaneously a reflection of the differences in political orientation-and arguably a degree of competition-among the Nordic states, despite a shared over-arching perspective on security, as outlined above. Illustrations include not only differences in institutional affiliations but also regarding regional focus (Baltic Sea vs. the Arctic) and policy framing (such as military dynamics vs. human security and feminist peace). In line with the argument of Browning and Joenniemi (2013), difference thus remains a defining feature of intra-Nordic security relations.

Third, the importance of European and Euro-Atlantic linkages is apparent. Both NATO and EU cooperation have deepened in parallel with Nordic cooperation, further integrating the Nordic countries into European and transatlantic structures (see further Bailes \& Sandö, 2014, pp. 37-40). Illustrations cover both EU-level support (as in the case of the EU civil protection mechanism, which has been invoked by Nordic countries a number of times) and Nordic contributions to EU-level processes, such as PESCO and the civil emergency pool of resources. On the NATO side, all Nordics are parts of civilian as well as military structures and are also integrated into practical cooperation such as exercises and training. Importantly, the political dynamics clearly posits intra-Nordic cooperation as a part of, not alternative to, European-level and transatlantic developments. By way of illustration, NORDEFCO Vision 2025 explicitly states: "The Nordic Defence Cooperation supplements and adds to the value of wider cooperation in international fora such as the UN, NATO, and the EU" (NORDEFCO, 2018, p. 1). Yet, the independent importance of NORDEFCO remains unclear. In a critical light, Nordic military defence cooperation could be viewed as a secondary structure, influenced by and reflecting first-order structures (EU and NATO/the US; cf. Bengtsson, 2011).

\section{A Case of Differentiated Integration?}

How can this picture of comprehensive yet varied cooperation in a multi-level setting be interpreted? This article argues that the lens of differentiated integration provides a fruitful analytical framework for further understanding Nordic security and defence cooperation. The literature on differentiated integration has been developed primarily in the context of $\mathrm{EU}$ integration, as a way to capture what is today an integral aspect of the European integration process, namely that there is both vertical differentiation (varying degree of centralization of political authority) and horizontal differentiation (variance in the number of participating countries) across policy areas. Long gone is a uniform model of EU integration: From Schengen to the Euro and defence cooperation, it is evident that not all member states are members to all parts of the EU, and not all parts of the EU are integrated to the same degree. In short, Schimmelfennig, Leuffen, and Rittberger (2015) characterize the EU as a system of differentiated integration, 
where variation is a key feature (see also Leruth, Gänzle, \& Trondal, 2019).

Nordic security and defence cooperation can be conceptualized as a case of differentiated integration. The various components of the policy field have developed at different speeds, advanced to different stages and are integrated to varying degrees. It can indeed be argued that a degree of vertical differentiation exists in the security and defence field. Interestingly enough, against the background of the Cold War and its aftermath, in general terms, the military defence sector has advanced further than the civil security sphere.

Also, horizontal differentiation is an apparent feature of Nordic security and defence cooperation. The five Nordic countries have not been part of the development of Nordic-level cooperation in the same way. Norway and Sweden stand out as leading the process, especially in the early years, whereas Denmark has been more hesitant but picked up speed in later years. Iceland, for its part, has a special approach due to its unique preconditions on the military side, lacking defence forces of its own. Finland, while not pushing the process, is an integral part of both civilian and military matters. Horizontal differentiation also features in the sense that alongside Nordic-level cooperation, there are a number of examples of bilateral and trilateral cooperation schemes that largely, but not fully, mirror the Nordic processes in terms of participation. The bilateral relationship between Finland and Sweden stands out as the most farreaching in the regional context.

A key theme in research on differentiated integration concerns explanations for variance in integration. Schimmelfennig et al. (2015) venture that two variables are key to explaining the outcome-interdependence and politicization. Interdependence is generally conceived of as a driver of integration, whereas politicization is an obstacle. Empirically, both interdependence and politicization vary across policy areas and countries. In short, the argument is that when high levels of interdependence and asymmetric politicization co-exist, differentiated integration is a likely outcome (Schimmelfennig et al., 2015, pp. 770-774; see also Leruth et al., 2019, pp. 1019-1020).

Applied to the Nordic security and defence context, we may initially conclude that high levels of security interdependence is a defining feature. This is evident not least concerning maintaining a credible defence by small states in a deteriorating security situation, preconditions for effective emergency and crisis management, and cost-effective solutions, especially on the military side. In short, the situation of the Nordic countries is conducive to deeper cooperation. However, there are also obstacles and limitations for proceeding in such a direction, which partly fall under the heading of politicization. Following de Wilde, Schimmelfennig et al. define politicization in the EU context as "an increase in polarization of opinions, interests or values and the extent to which they are publicly advanced towards the process of pol- icy formulation" (Schimmelfennig et al., 2015, p. 771). In the Nordic context, there are generally low levels of public political contestation, which may reflect common perceptions of interdependence but is arguably also a consequence of a common identity that not only lowers the threshold for cooperation in a general sense but may also facilitate cooperation in sensitive areas (see further Forsberg, 2013, pp. 1163, 1175). Having noted that, there are instances of politicization in the sense of positing Nordic cooperation as competing not least with NATO commitments (related to the issue of institutional foundations, but interpreted in different lights by for instance Denmark and Norway) - not to mention NATO cooperation and membership (in Finland and, especially, Sweden). Also, we see how military issues such as development of joint equipment and cost-sharing have been politicized in the past. This is indicative of a higher degree of differentiation on the military defence side than on civil security matters.

This picture of differentiated integration can be further problematized in light of the literature on security communities and stable peace. Scholarship on security communities is founded on the pioneering work of Karl Deutsch and colleagues on peace in the North Atlantic area (Deutsch et al., 1957). The defining dynamic regarding security communities concerns dependable expectations of peaceful change to the effect that members of the community know that any conflict among themselves will be settled by peaceful means. While Deutsch et al. (1957) focused on the importance of organization and communication as venues for reaching and maintaining such a state, later scholars, notably Adler and Barnett (1998), ventured a constructivist approach centred on value convergence, common identity and trust as drivers for the development, consolidation, and reproduction of security communities.

The literature on stable peace employs a similar logic in conceptualizing stable peace as a state in which members enjoy such high levels of trust that, no matter the severity of conflict among them, they would not consider (the threat or practice of) resolving conflict militarily. While related, the notion of stable peace is broader in scope than that of the security community, as the latter also assumes the presence of reciprocal identification and a common we-feeling (see further Bengtsson, 2000, 2009; Ericson, 2000; Kacowicz \& Bar-Siman-Tov, 2000).

The Nordic region is commonly recognized as a primary case of a regional security community or zone of stable peace. From a conflictual and war-torn past, the region now maintains two centuries of peaceful relations including the non-violent breakup of the union of Sweden and Norway in 1905 and the peaceful resolution of the Åland conflict between Finland and Sweden after World War I (for problematization see Jerneck, 2009, pp. 210-215; also to be noted is the fact that Norway and Sweden kept defensive war plans against each other for at least two more decades; see Bengtsson, 2000; Ericson, 2000). Analysing the causal dynamics of the develop- 
ment of the Nordic stable peace is beyond the scope of this article (although shared culture and language, transactional logic of trade, communication and exchange, democratization, development of civil society, common practices, and a shared realization of smallness in international relations may reasonably all be part of such an analysis).

While few would dispute labelling the Nordic region a security community or zone of stable peace, it may be argued that the differentiated integration established above makes the Nordic region something of an atypical case. Not only is the low degree of institutionalization noteworthy given the long history and, in parts, depth of cooperation (in contrast to, say, the EU), formal organization, let alone harmonization, from the top has not been a defining feature of the Nordic security community. Moreover, and in a different light, the Nordic zone of stable peace stands out because it seems to rest (at least in the past) on a degree of what Browning and Joenniemi (2013, p. 497) refer to as internal "asecuritization," and, in consequence, difference. Instead of securitization being the driving force of integration and common policy development a natural extension (as in the case of the EU), Nordic cooperation has largely been characterized by the absence of politicizing internal security matters (apart from instances on the military side mentioned above). Differences in orientation and policy have therefore remained and the relatively few common projects to be found in the security and defence area thus far have been primarily technical in nature. This forms an additional or competing explanation for the absence of security and defence cooperation during the Cold War as well as for the differentiated nature of such cooperation in the contemporary era.

\section{Conclusion: A Formative Moment for Nordic Security and Defence Cooperation?}

Nordic cooperation on security and defence has developed over the last decade into a central aspect of Nordic cooperation. On the Nordic level, military defence cooperation has advanced through NORDEFCO, whereas civil security cooperation takes place primarily within the 'Haga' process. The proposals of the Stoltenberg report have been partially implemented, furthering military as well as civilian matters. In addition to these schemes for cooperation, a number of bilateral and trilateral processes have been initiated. It should be noted that these intra-Nordic processes, simultaneously in different ways, are part of, stimulated by, and conditioned by developments on the European, transatlantic, and global levels: Nordic cooperation is in that sense a secondary structure which cannot be fully understood in isolation from European (and even global) developments.

Nordic cooperation on security and defence can be conceptualized as a case of differentiated integration. Different sectors of cooperation have developed in different ways, at different speeds, and with different driv- ing forces. Likewise, the Nordic countries have chosen to participate in various sectors to varying degrees and at different points in time. It seems, however, that with the fundamental shift in the regional security environment due to Russia's annexation of Crimea and war in Ukraine, there is movement in the direction of a more uniform approach to Nordic security and defence cooperation (also in the civilian areas).

While progress over the last decade has been substantial, it also appears that there are limits to how far the Nordic countries hitherto have been willing to go. In part, this is a reflection of the varying institutional foundations of the Nordics, with different constellations of membership in the EU and NATO. Moreover, there are obvious national reflexes that prohibit proactive pooling and sharing in military matters. The Haga II vision of a robust and resilient region without internal borders is far from reality. The conclusions of these observations are not easily interpreted. Is the experience of decadelong cooperation on security and defence pointing towards learning, a convergence of thinking, and development of a more common strategic culture, as would be expected from a conventional security community perspective? Or are common processes also to a degree sharpening national egoism and perceptions of variation primary, in essence enhancing politicization? Will difference remain a key feature of Nordic security and defence dynamics?

While these questions are generally relevant for assessing the political dynamics of the last decade, they take on special salience at the time of writing. The Coronavirus pandemic has brutally brought the issue of (the limits of) Nordic solidarity to the fore. As the acute phase of the pandemic withers (in Europe), the differences in Nordic approaches to crisis management appear clearly, both regarding border protection and security approaches, as well as public health and medical strategies. The crisis demonstrates the limits of, but importantly also the potential for, Nordic cooperation in areas such as security of supply, joint procurement, and border-free regimes for the pooling of human resources and joint management of crises and security challenges. But whether there is the political will and trust to pursue this potential remains an open question.

An existential rift among the Nordic states (especially between Sweden and the other four) is now obvious; schemes of cooperation and achievements in integration have in part broken down and distrust is partially replacing the high level of trust that was once a sign of the Nordic region. This in turn spurs a fundamental practical and theoretical question concerning the dynamics of security communities and stable peace. While policy development, as well as academic research, naturally has focused on the establishment and consolidation of stable peace and security communities and the development of trust as a key variable, much less attention has been directed to issues of challenges, reversibility, and decay. The Nordic case may thus once again prove to be princi- 
pally important in scholarship on, as well as in the practice of, international relations.

\section{Acknowledgments}

The author wishes to thank two anonymous reviewers and the editors of this thematic issue for constructive comments on an earlier version of this text. Research for this article was made possible by a grant from the Swedish Civil Contingencies Agency (MSB), which is hereby gratefully acknowledged.

\section{Conflict of Interests}

The author declares no conflict of interests.

\section{References}

Adler, E., \& Barnett, M. (1998). Security communitites. Cambridge: Cambridge University Press.

Bailes, A. J. K., \& Sandö, C. (2014). Nordic cooperation on civil security: The 'Haga' process 2009-2014 (FOI-R3944-SE). Stockholm: FOI.

Bengtsson, R. (2000). Trust, threat and stable peace: Swedish great power perceptions 1905-1939. Lund: Lund University.

Bengtsson, R. (2009). Den internationella fredens anatomi [The anatomy of international peace]. In M. Jerneck (Ed.), Fred i realpolitikens skugga [Peace in the shadow of realpolitik] (pp. 33-48). Lund: Studentlitteratur.

Bengtsson, R. (2011). Norden in the Arctic and Baltic Sea region. In T. Tiilikainen \& K. Korhonen (Eds.), Norden: Making a difference? Possibilities for enhanced Nordic cooperation in international affairs (pp. 53-67). Helsinki: The Finnish Institute of International Affairs.

Bjarnason, B. (2020). Nordic foreign and security policy 2020: Climate change, hybrid and cyber threats and challenges to the multilateral, rules-based world order. Stockholm: Government Offices of Sweden. Retrieved from https://www.government.se/ 49f308/contentassets/c128b79d0e9143469e7df836 48eddb3c/nordic_foreign_security_policy_2020_ final.pdf

Browning, C. S., \& Joenniemi, P. (2013). From fratricide to security community: Re-theorising difference in the constitution of Nordic peace. Journal of International Relations and Development, 16, 485-513.

Deutsch, K., Burrell, S. A., Kann, R. A., Lee, M., Lichterman, M., Lindgren, R. E., . . . van Wagenen, R. W. (1957). Political community and the North Atlantic area. New York, NY: Greenwood Press.

Ericson, M. (2000). A realist stable peace: Power, threat and the development of a shared NorwegianSwedish democratic security identity 1905-1940. Lund: Lund University.

Forsberg, T. (2013). The rise of Nordic defence cooper- ation: A return to regionalism? International Affairs, 89(5), 1161-1181.

Haugevik, K., \& Sverdrup, U. (2019). Ten years on: Reassessing the Stoltenberg report on Nordic cooperation. Oslo: NUPI.

Herolf, G., \& Håkansson, C. (2020). The new European security architecture. In B. Fägersten (Ed.), The Nordics and the new European security architecture (UI Report No. 3/2020, pp. 7-15). Stockholm: Swedish Institute of International Affairs.

Hultqvist, P. (2020, July 28). Värdlandsstödsavtal med Finland planeras [Host nation support agreement with Finland planned]. Dagens Nyheter. Retrieved from https://www.dn.se/debatt/vardlandsstodsavtalmed-finland-planeras

Jerneck, M. (2009). Den långa svenska freden: En fråga om småstatspolitik eller stormaktsdominans? [The long Swedish peace: A question of small state politics or great power dominance?]. In M. Jerneck (Ed.), Fred i realpolitikens skugga [Peace in the shadow of realpolitik] (pp. 199-226). Lund: Studentlitteratur.

Kacowicz, A. M., \& Bar-Siman-Tov, Y. (2000). Stable peace: A conceptual framework. In A. M. Kacowicz, Y. Bar-Siman-Tov, O. Elgström, \& M. Jerneck (Eds.), Stable peace among nations (pp. 11-35). Lanham: Rowman \& Littlefield Publishers.

Leruth, B., Gänzle, S., \& Trondal, J. (2019). Exploring differentiated disintegration in a post-Brexit European Union. Journal of Common Market Studies, 57(5), 1013-1030.

Lindberg, J. (2018). Finnish-Swedish defence cooperation advances. Baltic Rim Economies, 2018(4), 18.

MSB. (2009). Hagadeklarationen: Nordiskt ministermöte rörande samhällskydd och beredskap [The Haga declaration: Nordic ministerial meeting on civil contingencies and emergency preparedness]. Karlstad: Swedish Civil Contingencies Agency. Retrieved from https://www.msb.se/contentassets/ ffe85074eaa6491a91d9d29aaf8018d0/haga-ideklarationen.pdf

MSB. (2013). Haga II deklarationen [The Haga II declaration]. Karlstad: Swedish Civil Contingencies Agency. Retrieved from https://www.msb.se/contentassets/ ffe85074eaa6491a91d9d29aaf8018d0/haga-iideklarationen.pdf

MSB. (2018). Så bygger vi säkerhet i Norden: Ett svenskt myndighetsperspektiv. [How to build security in Norden: Perspectives from Swedish government agencies]. Karlstad: Swedish Civil Contingencies Agency.

NATO. (2020). Civil preparedness: Strategic areas. Brussels: NATO Headquarters. Retrieved from https:// www.nato.int/cps/en/natohq/topics_49158.htm

NORDEFCO. (2014). Nordefco annual report 2014. Oslo: Ministry of Defence. Retrieved from https:// www.nordefco.org/Files/NORDEFCO_arsrapport_ 2014_compressed.pdf

NORDEFCO. (2018). Nordic defence cooperation vision 2025. Oslo: Ministry of Defence. Retrieved from 
https://www.nordefco.org/Files/nordefco-vision2025-signed.pdf

NORDEFCO. (2019). Nordefco annual report 2019. Stockholm: Ministry of Defence. Retrieved from https://www.nordefco.org/Files/Nordefco\% 20Annual\%20Report\%202019\%20Webb.pdf

NORDEFCO. (2020). About NORDEFCO. Stockholm: Ministry of Defence. Retrieved from https:// www.nordefco.org/the-basics-about-nordefco

Nordic Council. (2019, October 30). Utrikesministrarna gör en ny säkerhetspolitisk utredning [Foreign ministers to conduct a new security-political inquiry]. Nordiskt samarbete. Retrieved from https://www. norden.org/sv/news/utrikesministrarna-gor-en-nysakerhetspolitisk-utredning

Regeringen. (2015). Vi fördjupar det nordiska försvarssamarbetet [We are deepening the Nordic defence cooperation]. Dagens Nyheter. Retrieved from https://www.regeringen.se/debattartiklar/ 2015/04/vi-fordjupar-det-nordiskaforsvarssamarbetet

Regeringen. (2016). Sverige fördjupar sitt fredstida samarbete med Danmark [Sweden deepens its peace-time cooperation with Denmark]. Retrieved from https://www.regeringen.se/artiklar/2016/01/ sverige-fordjupar-sitt-fredstida-forsvarssamarbetemed-danmark

Regeringen. (2018). Trilateral statement of intent. Retrieved from https://www.government.se/49993c/ globalassets/government/dokument/ forsvarsdepartementet/2018/trilateral-statementof-intent-8th-may-2018.pdf

Regeringen. (2020). Nordic Foreign Ministers receive report on Nordic cooperation on foreign and security policy. 6 July 2020. Retrieved from https://www. government.se/press-releases/2020/07/nordicforeign-ministers-receive-report-on-nordiccooperation--on-foreign-and-security-policy

Regjeringen. (2011). Nordic declaration on solidarity. Oslo: Norwegian Government. Retrieved from https://www.regjeringen.no/globalassets/upload/ ud/vedlegg/nordisk-samarbeid/the_nordic declaration_on_solidarity.pdf

Saxi, H. L. (2019). The rise, fall and resurgence of Nordic defence cooperation. International Affairs, 95(3), 659-680.

Schimmelfennig, F., Leuffen, D., \& Rittberger, B. (2015). The European Union as a system of differentiated integration: Interdependence, politicization and differentiation. Journal of European Public Policy, 27(6), 764-782.

Stoltenberg, T. (2009). Nordic cooperation on foreign and security policy: Proposals presented to the extraordinary meeting of the Nordic foreign ministers in Oslo on 9 February 2009. Oslo: Ministry of Foreign Affairs. Retrieved from https://www.regjeringen.no/ globalassets/upload/ud/vedlegg/nordicreport.pdf

\section{About the Author}

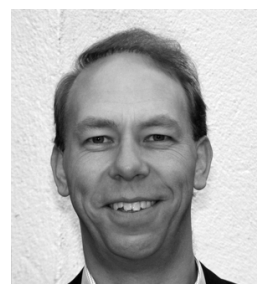

Rikard Bengtsson (PhD) is an Associate Professor of Political Science at Lund University, Sweden. His research interests and teaching profile include security and defence issues, global political economy, and global organization and governance, with an empirical focus on the Baltic Sea region and the European Union. Between 2012 and 2016, Bengtsson served as Senior Advisor at the Office of Strategic Analysis in the Prime Minister's Office and the Ministry for Foreign Affairs, Sweden. 